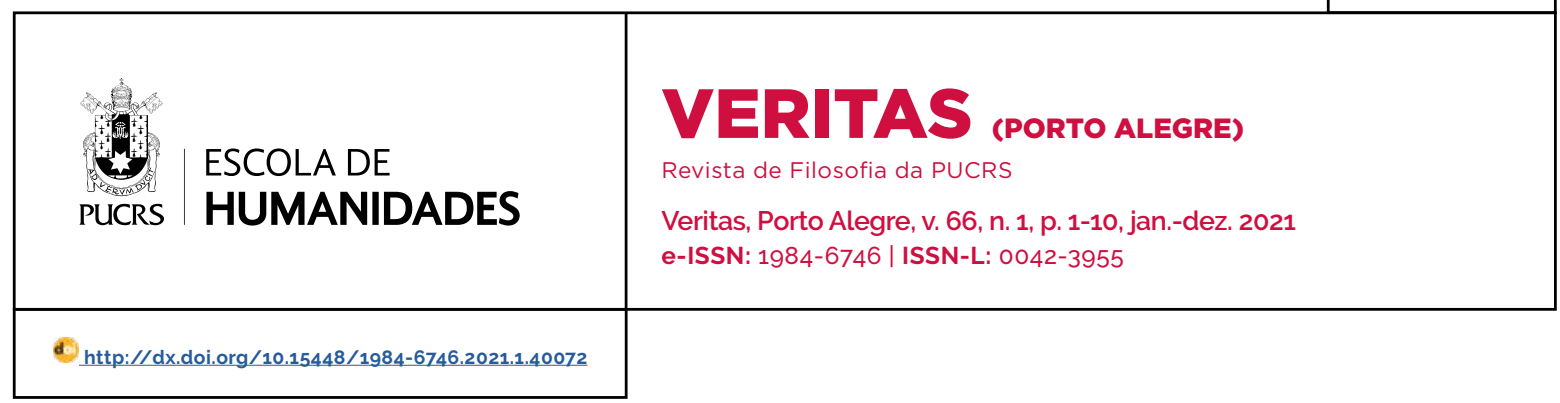

SEÇÃO: TRADUÇÃO

\title{
Três escritos breves de Heidegger ${ }^{\mathbf{1}}$
}

Three brief writings by Heidegger

Tres breves escritos de Heidegger

\section{Norberto Bobbio²}

José Francisco de Assis ${ }^{3}$ orcid.org/0000-0002-5339-8652 prof.dias.br@gmail.com

\section{Daniela Valentini ${ }^{3}$}

orcid.org/0000-0002-6475-3955 danyval@hotmail.it

Recebido em: 2 fev. 2021. Aprovado em: 13 abr. 2021. Publicado em: 11 maio 2021.

\section{(c) (1)}

Artigo está licenciado sob forma de uma licença Creative Commons Atribuição 4.0 Internacional.
Enquanto o existencialismo vulgar faz tanto barulho revolvendo águas turvas, Martin Heidegger, pai do existencialismo (por quanto não tenha reconhecido essa paternidade), continua pacatamente o seu caminho a passos lentíssimos e circunspectos; sem impaciências, com sobriedade de palavras, com um esforço sempre mais visivel de atingir uma limpidez essencial fora do emaranhado das palavras da cultura corrente (que mostra não dar nenhuma importância), e uma simplicidade primitiva que olha com olhos novos e virgens o problema dos problemas, o problema da verdade do Ser. Esse caminho o conduz sempre mais distante do existencialismo e o encaminha rumo a uma meta tão fora do modo comum de pensar e de comunicar os próprios pensamentos que não me parece licito continuar a falar de filosofia em relação a ele (e nem mesmo de uma filosofia da contemplação do Ser ou de uma filosofia da revelação, como poderiam dar a entender algumas expressões), rumo a uma problemática de que me parece dificil, por ora, tentar uma interpretação (se não em termos puramente psicológicos), tanto é ousada e gratuita - ousadamente gratuita - a impostação dos próprios termos do problema; tanto é preciosa, extravagante, caprichosa a linguagem que se vale sempre mais de metáforas e de imagens encorpadas; tanto se torna incerto - sobre aquele plano de radical e declarada antitradição, naquela atmosfera de brilho auroral na qual se coloca e busca conduzir o leitor - a fronteira entre a instância da explicação racional e a sugestão poética; e se mostra equivoco o nexo entre a alusão poética (indubitavelmente buscada e almejada) da linguagem metafísica e a evidência metafísica da linguagem poética.

De todo modo, por ora, não importa o juízo, que poderia ser imaturo, sobre o resultado da investigação heideggeriana, posto que a presente análise é intencionalmente descritiva (uma filosofia "contracorrente", como essa de Heidegger, é preciso deixar sedimentar, porque, querendo en-

\footnotetext{
Artigo original de Norberto Bobbio intitulado originalmente: "Tre scritti brevi di Heidegger", extraido da Rivista di Filosofia, v. 39, n. 3. p. 1-16, 1948.

2 Tradução do original italiano de José Francisco de Assis Dias e Daniela Valentini; revisão técnica e tradução das citações em alemão de Roberto S. Kahlmeyer Mertens.

3 Universidade Estadual do Oeste do Paraná (UNIOESTE), Toledo, PR, Brasil.
} 
frentá-la logo, existe o risco de não a aferrar ou, o que é pior, de ser aferrado por ela); importa indicar preliminarmente que o caminho percorrido pelo pai do existencialismo é marcado pelo desenvolvimento de um só - e do menos vistoso - dos temas propostos em Ser e tempo, que depois se tornaram vigoroso fermento da filosofia contemporânea: o tema da existência da verdade. A esse tema Heidegger dedicou dois ensaios, o primeiro de apresentação explicativa do problema (Vom Wesen der Wahrheit - Da essência da verdade), o segundo, digamos assim, de validação histórica (Platons Lehre von der Wahrheit - A doutrina de Platão sobre a verdade); chegando, por fim, a um ensaio de entonação polêmica (Brief über den Humanismus - Carta sobre o humanismo), à definição da própria posição através de um movimento de ataque e defesa; ataque à tradição metafisica da filosofia ocidental na sua totalidade e defesa das mais insistentes objeções aos mal-entendidos do "existencialismo".

Quem quer que tenha lido Ser e tempo não pode não lembrar que um longo parágrafo 4 era dedicado, naquele livro, ao desenvolvimento da critica da concepção tradicional da verdade e à exposição de uma nova concepção, que não se punha como abatimento da antiga, mas como sua reinterpretação genuína, como sua verificação e semelhanças. A tese crítica, ali sustentada, era que a concepção tradicional, presente em toda a história da filosofia ocidental, a começar por Aristóteles, não conhecia outro modo de considerar a verdade senão como "adaequatio rei et intelectus", como concordância (Uebereinstimmung) entre sujeito e objeto. Enquanto tal, a verdade tem sede no juizo, onde só do juízo se pode dizer que é verdadeiro ou falso. Mas a verdade - se perguntava Heidegger - tem sede no juízo de modo originário? O modo de compreender a verdade como adequação é o modo originário, o modo que funda e exclui todo outro modo de considerar a verdade? Essa pergunta o conduz a analisar a essência da verdade; e através dessa análise chegou às conclusões que põem em discussão e abalam a concepção tradicional. Dizer que o juízo é verdadeiro significa que ele descobre o ente em si mesmo, isto é, enuncia, mostra, "deixa ver" o ente no seu ser-descoberto (Entdeckt-sein), poderiamos dizer, na sua nudez. A verdade do juízo consiste, portanto, na operação do "descobrimento", o que mostra como a verdade originalmente não tem a estrutura de uma adequação entre o conhecer e o objeto no sentido de uma correspondência entre um ente (o sujeito) e um outro ente (o objeto).

Dessa interpretação da verdade como "desvelamento", Heidegger buscava também dar uma convalidação histórica, mostrando que essa concepção da verdade era exatamente aquela que a filosofia mais antiga prenunciou e expressou na palavra grega $\alpha \lambda \lambda \dot{\theta} \theta \varepsilon \iota \alpha$, a qual significa a propriedade de não se encobrir, que Heidegger traduz, não sem entendimento de tradução literal, com Unverborgenheit (literalmente "não ocultação"). A verdade, entendida como Unverborgenheit, quer dizer, em outras palavras, que o ente se mostra a partir de um originário ser-encoberto (Verborgenheit - oculto ou encoberto), quer dizer, retornando à expressão da qual se partiu, o ser-desvelado do ente.

Passando, depois, a inserir a tese da verdade (como desvelamento daquilo que é escondido) na analítica da existência humana, Heidegger, nas mesmas páginas de Sein und Zeit, precisava que a verdade como desvelamento é um modo de ser do ser-ai (Dasein), enquanto ser-ai é aberto para o mundo. Essa abertura - ou mais literalmente essa "revelação" - ele denominou Erschlossenheit. Na mesma obra, em um passo precedente (HEIDEGGER, p. 132)5, havia já afirmado que o ser-ai (Dasein) é a sua abertura; aqui ainda reforça que a abertura é aquele modo fundamental do ser-ai, em base ao qual ele é o seu "ai". Com a abertura e mediante a abertura do homem se acompanha o ser-desvelado do ente; e, portanto, somente com a abertura, somente enquanto o homem é, na sua estrutura fundamental, aberto rumo

\footnotetext{
Trata-se do $\S 44$ (p. 212-230), contido no sexto capítulo que desenvolve o tema do "cuidado" (Parte I).

5 Estamos cientes da imprecisão metodológica em todas as citações diretas feitas por Norberto Bobbio, que referenciou somente a página, sem indicar o autor e o ano; porém, é insanável, pois não temos como saber quais edições ele utilizou quando escreveu o artigo em 1948 (N.T.).
} 
àquilo que é, ele atinge o fenômeno originário da verdade. Enfim, o fato que pertença à constituição existencial do ser-ai a abertura, significa, em outras palavras, que o ser-ai é na verdade.

Mas o ser-ai não é somente e exclusivamente na verdade. Como ente decaído, posto constitutivamente em uma situação de decadência (Verfallen), é também, constitutivamente, na não verdade. Ao seu ser-aberto (Erschlossenheit) contrapõe-se o seu ser-fechado (Verschlossenheit); paralelamente, ao ser-descoberto (Entdecktheit) do ente se contrapõe o ser-falseado (Verstelltheit). Por isto, a afirmação: o ser-aí é na verdade, significa originariamente o mesmo que: o ser-ai é na não verdade. O homem deve continuamente garantir aquilo que é já descoberto contra a falsificação, e aproximar-se sempre de novo daquilo que é descoberto para dele se assegurar. A verdade, portanto, deve ser continuamente sacada; e o ente deve vir continuamente retirado de seu ser-encoberto.

Retornando à crítica da concepção tradicional da verdade da qual partiu, depois de haver procurado explicar como foi possivel passar da concepção originária da verdade como o ser-descoberto do ente, diante da abertura do ser-aí, à concepção tradicional da adaequatio adequação, o texto heideggeriano termina com esta conclusão: "Não é o juizo a sede primária da verdade, mas, ao inverso, o juízo como modo da apropriação do ser-descoberto e como modo do ser-no-mundo se funda no descobrir, na abertura do ser-ai" (HEIDEGGER, p. 226). ${ }^{6}$

Esse mesmo tema da essência da verdade constitui objeto dos dois últimos ensaios heideggerianos, apresentados ao público depois de muitos anos de silêncio: Vom Wesen der Wahrheit - Da essência da verdade, do qual só recentemente apareceu a tradução francesa de título De l'essence de la verité, 7 a única que nos foi possivel considerar aqui, já que até agora estivemos impedidos de ter em mãos o texto original, quase impossivel de encontrar; e Platons Lehre von der Wahrheit ${ }^{8}-A$ doutrina de Platão sobre a verdade, cuja primeira edição no Anuário "Geistige Ueberlieferung" - Tradição espiritual, estabelecida por E. Grassi, em 1942, passou quase despercebida, não só pela situação de guerra, mas também porque suas recensões foram proibidas e interditada a sua publicação em estrato. Embora seja recente a publicação, a ideação e a elaboração original de ambos os ensaios remontam a muitos anos atrás, isto é, ao período em que apareceram - antes do longo silêncio, interrompido somente, salvo engano, pelo escrito sobre poesia de Hölderlin (1936) - os últimos escritos filosóficos: Was ist Metaphysik? (1929) - Que é metafísica? - e Vom Wesen des Grundes (1929) - Da essência do fundamento. O primeiro, de fato, dos dois ensaios, acima citados, foi extraido de uma conferência ministrada no outono e no inverno de 1930, em Bremen e em Marburgo, e no verão de 1932, em Dresden; o segundo, escrito em 1940 para uma conferência em um pequeno cenáculo, deriva de lições públicas ministradas nos anos 1931-1932 e 1933-1934.

O escrito sobre a essência da verdade se apresenta como uma retomada e um desenvolvimento do problema da verdade, como fora impostado em Sein und Zeit: critica da concepção tradicional e exposição da concepção que se põe como originária. Segundo a teoria da adequação, como se viu, a verdade consiste em uma certa relação que se estabelece entre o enunciado e a coisa. Nesse novo ensaio se precisa que a essência dessa relação está no apresentar (Vorstellen, no significado etimológico de "pôr diante"), isto é, em tornar presente a coisa, em deixar surgir a coisa diante de nós como objeto. Mas essa apresentação tem lugar somente enquanto e no momento em que o ente, aquilo que é presente, percorre, atravessa o domínio aberto ao nosso encontro. Retorna o tema da abertura do homem ao ser. Somente muda a terminologia com o abandono da palavra pouco usual Erschlossenheit (descerramento) e a volta a um termo mais corrente

\footnotetext{
6 Este é um trecho do $\S 44$ de Ser e Tempo, a paginação é do original alemão. Muito provavelmente é uma tradução feita pelo próprio Bobbio (N.T.)

7 Na coleção "Philosophes contempraines. Textes et études" dos editores E. Nauwelaerts de Louvain e J. Vrin de Paris, 1948. A tradução e a longa introdução (minuciosamente e diligentemente expositiva) são curadas por A. De Waelhens e W. Biemel.

8 E o quinto volume da elegantíssima coleção "Ueberlieferung und Auftrag", dirigida por E. Grassi, com a colaboração de W. Szilasi, publicada por A. Francke de Berna, 1947. Contém também o Brief über den Humanismus, do qual se falará posteriormente.
} 
Offenheit (abertura), ou também Offenständigkeit (o caráter de estar aberto). Essa nova terminologia, além disso, permite estabelecer, se não uma derivação, uma aproximação (sobre a qual é bom chamar a atenção) à família de termos relativos ao conceito de revelação (Offenbarung). Também aqui, como em Sein und Zeit, desse conceito de abertura, do "estar aberto" do homem, Heidegger parte para superar a concepção tradicional da verdade como conformidade. Essa abertura, de fato, não é produzida pela apresentação, mas é investida e assumida dessa como campo de relação. E é mediante essa abertura que aquilo que se revela (das Offenbare - o revelado) pode se tornar a medida diretiva de uma apresentação adequada. O comportamento aberto (cada relação de abertura é um comportamento) deve deixar-se guiar por esta medida. Mas, se é somente mediante a abertura do comportamento que a conformidade do enunciado se torna possivel, então daqui resulta que aquilo que torna possivel a conformidade possui um direito mais originário a ser como a essência da verdade. Logo: a verdade não há a sua sede originária no juízo, mas no revelar-se do ente à abertura do homem, que torna possivel o juizo.

No que diz respeito à pesquisa contida em Sein und Zeit, o ensaio sobre a essência da verdade insere nessa problemática um tema novo, aquele da liberdade, e desenvolve mais amplamente um tema implícito, aquele da não verdade. O tema da liberdade se oferece imediatamente sem uma precisa justificação: é um daqueles temas que revelam que o jogo ao qual se confia Heidegger, às vezes, é demasiado hábil, demasiado tenso para ser compreendido sem um esforço além que de meditação e de imaginação, quase uma caprichosa irregularidade que dá à sua obra aquele caráter tão singular de aventura do pensamento que atrai e afasta, mas às vezes também se esgota em si mesma. A pergunta, na resposta à qual intervém o tema da liberdade, é a seguinte: posto que a verdade está na abertura do comportamento, o que funda essa abertura e, portanto, o que rende possivel a apresentação que se resolve na conformidade do juizo com a coisa? O fundamento da abertura, responde Heidegger, é a liberdade. A abertura, em outras palavras, não é possivel se não quando o homem é liberado por esse campo de encontro ao interno do qual somente pode aparecer aquilo que é manifesto. Mas para se libertarem, precisam ser livres em relação àquilo que é manifesto no seio do ser-aberto. "A abertura do comportamento, aquilo que torna intrinsecamente possivel a conformidade, funda-se sobre a liberdade. A essência da verdade é a liberdade" (HEIDEGGER, p. 79).9

Mostra-se o perigo que esse pôr a verdade na liberdade abandone a verdade ao arbitrio humano, e a reconduza à subjetividade. Diante desse perigo (uma filosofia da "revelação" nada teme mais que o subjetivismo), Heidegger esclarece que a liberdade não deve ser entendida em nenhum dos dois significados tradicionais, nem como arbítrio, nem como falta de constrição: a liberdade é o abandono ao desvelamento do ente como tal, é aquilo que "deixa ser" o ente. Esse "deixar-ser" significa "dar-se ao ente", significa que nós nos expomos ao ente como tal e nos abandonamos à abertura dentro da qual todo ente entra e reside, levando-a, por assim dizer, consigo. Mas esse "deixar-ser" o ente, esta liberdade, é a existência, no conhecido sentido heideggeriano de ex-sistere, de ser para fora (hinausstehen), de sair rumo ao ser. "A existência, radicada na verdade como liberdade, é o expor-se ao ser-desvelado do ente como tal" (HEIDEGGER, p. 86). A existência do homem histórico começa no momento em que o primeiro pensador é tocado pela verdade, quando a verdade for entendida no seu sentido originário e fundamental de desvelamento do ente que não mais se esconde (Unverborgenheit), mas se revela a partir da obscuridade inicial em que é envolvido e que o esconde (Verborgenheit), ou, para adotar o termo do tradutor francês, a partir da obnubilação (a tradução literal de Verborgenheit seria "escondidez", ou, se parece menos áspero, "escondidade" ou "ocultidade").

Dizer que a verdade desvela o ente implica que o ente é velado, escondido, obnubilado. A verdade

9 No original alemão (em numeração standard), a página dessa passagem é a 81 e não a 79 (N. T.) 
é o não ser escondido do ente, enquanto o ente é escondido: sem o ser-escondido e o velamento não teria sentido falar de ser-descoberto e de descobrimento. Nesses termos, o problema da verdade implica o problema da não verdade. A implicação é tão rigorosa que "o problema da essência da verdade não atinge o seu domínio original senão quando a visão preventiva da plena essência da verdade permite englobar, no desvelamento desta, a reflexão sobre a não-verdade" (HEIDEGGER, p. 88).

A passagem da pesquisa sobre a verdade à pesquisa sobre a não verdade é marcada pela aparição de uma nova noção: aquela de Gestimmtheit - afinação - ou Stimmung - tonalidade afetiva, que é a disposição afetiva fundamental (por quanto não seja um sentimento, nem um estado de ânimo no sentido comum da palavra) rumo ao ente na totalidade, disposição que é gerada pela liberdade entendida como abandono ao desvelamento do ente na totalidade, como deixar-ser o ente na totalidade. Em outras palavras: a liberdade, que deixa ser o ente na totalidade. gera um acordo afetivo com o ente na totalidade, que permanece sobre o fundo - principalmente ignorado e posto de lado no horizonte das preocupações e dos cálculos quotidianos - do processo de desvelamento do ente particular. Por quanto a revelação do ente na totalidade penetre o comportamento do homem, ele permanece indeterminado e indeterminável. E quanto mais se alarga no nosso saber corrente o conhecimento das determinações particulares, tanto mais vem rejeitado na sombra o ente na totalidade. De um lado nós, portanto, desvelamos o ente particular nas suas determinações; mas a par e passo com este desvelamento o ente na totalidade se oculta, esconde-se, isto é, procede também a "ocultação" (Verbergung) ${ }^{10}$ do ente na totalidade. Aclara-se, assim, a implicação da verdade com a não verdade, como implicação do "descobrir" e do "esconder". "Em si, o deixar-ser lque é próprio, como se viu, da liberdade] é simultaneamente um velamento. Na liberdade existente do Dasein se realiza o velamento do ente na totalidade". Esse ente na totalidade, assim escondido, é a não verdade entendida como Verborgenheit, isto é, como obnubilação. A obnubilação é aquilo que rejeita à verdade o desvelamento. E, portanto, a não verdade originária própria da essência da verdade; e é mais antiga desse ou daquele ente; e mais antiga do próprio deixar-ser que desvelando esconde. Como explica o tradutor-comentador, a obnubilação é o pressuposto da verdade como desvelamento; é o fundamento sobre o qual se funda a ação mesma do desvelar, donde resulta que a relação entre verdade e não verdade não é de oposição lógica, mas é a relação que intercorre entre o fundamento e aquilo que é fundado (HEIDEGGER, p. 45). A não verdade como obnubilação é a pré-verdade.

O ocultamento dessa não verdade originária, literalmente, o ocultamento do que se esconde (die Verbergung des Verborgenen) é o mistério, do qual o homem é circundado e dominado. Dado que o desvelamento é sempre somente parcial, o ser na totalidade é como arremessado na obnubilação e essa obnubilação faz resplandecer o mistério do Ser. Esse mistério enfaixa o homem; mas o homem (o homem do "cuidado") deixando ser o ente particular para correr atrás dos próprios projetos e das próprias necessidades de todo dia, esquece o mistério. Mas o mistério esquecido não é eliminado: enquanto se renega no esquecimento e pelo esquecimento, constrange o homem histórico a contentar-se com a vida quotidiana e os seus falsos poderes. A humanidade realiza o próprio mundo partindo das próprias necessidades e cálculos; e, esquecida do ente em totalidade, aceita dele as próprias medidas. E se engana sobre a essência autêntica dessas medidas tanto mais gravemente quanto mais considera a si mesmo como medida de todas as coisas.

O esquecimento do mistério é o segundo aspecto com o qual se apresenta, segundo Heidegger, a não verdade: a não verdade como errância (die Irre). Também aqui é evidente a tentativa de

10 O tradutor francês traduz Verbergung, em falta de termo melhor, com "dissimulation"; mas é tradução equivocada e enganosa. Verdadeiramente, havendo traduzido Verborgenheit com "obnubilação", dever-se-ia agora traduzir Verbergung com "obnubilamento". Mas deixo imaginar o efeito grotesco que viria - querendo render fielmente a expressão várias vezes usada no texto, die Verbergung des Verborgenen - por dever dizer a cada momento: "o obnubilamento do obnubilado"! 
interpretar o problema do erro, assim como aquele da verdade, partindo do significado originário da palavra. O homem erra de uma coisa quotidiana à outra: nesse irrequieto, preocupado errar, o homem esquece o mistério, e cai na não verdade do esquecimento da obnubilação originária que fundamenta a verdade. Também a errância pertence, como o mistério, à essência originária da verdade. Heidegger o define como "a antiessência fundamental da essência originária da verdade". Mistério e errância se encontram e se implicam na essência mesma da verdade, e envolvem o homem na obra de desvelamento da verdade. A existência - disse Heidegger - é grávida de mistérios por quanto de mistérios esquecidos: "eis porque o homem está, na existência do seu Dasein. submisso simultaneamente ao reino do mistério e à ameaça da errância" (HEIDEGGER, p. 98). O homem é na não verdade enquanto a verdade é escondida, e quanto mais ele desvela o ente nas suas determinações particulares, mais o oculta na sua totalidade; então o homem é ainda na não verdade enquanto esquece que a verdade está escondida no mistério. Se a verdade originária se entendesse como o oposto da verdade, os dois aspectos da não verdade (como mistério e como esquecimento do mistério ou errância) seriam contraditórios. Mas, ao invés, a verdade emerge de uma não verdade fundamental e se disperde em uma não verdade corrente, isto é, está entre o mistério que implica a rejeição de uma verdade total, a errância que, como esquecimento do mistério, representa a satisfeita aceitação da verdade parcial. Em ambos os casos a verdade leva consigo a não verdade: no primeiro caso, porque se destaca do fundo do mistério sem poder iluminá-lo repentinamente e totalmente; no segundo, porque, exatamente enquanto desvelamento daquilo que é escondido, esquece a própria obnubilação e o velamento daquilo que é escondido, isto é, o mistério.

No segundo ensaio, Heidegger busca surpreender historicamente, com uma investigação interpretativa do mito platônico da caverna, o momento da passagem da concepção originária da verdade à concepção tradicional. Em Sein und
Zeit, a análise histórica da concepção tradicional não fora além de Aristóteles, considerado o principal iniciador e o mais típico representante dela. Aqui, ao invés, vem em questão a teoria platônica do conhecimento, como é exposta no célebre mito do Livro VII da República. O mito nos apresenta quatro graus de verdade, entendida no sentido originário de revelação daquilo que é velado. Na primeira fase, o homem, ainda prisioneiro, vê sombras; na segunda, tiradas as correntes, ainda cego pela luz à qual o olho não está habituado, considera aquilo que viu até agora, as sombras, como mais verdadeiro do que aquilo que agora se lhe mostra; na terceira, fora da caverna, mira as ideias; de volta à caverna, na quarta e última fase, não se encontra mais confortável, em perigo de sucumbir à prevalência da verdade ali dominante. Não há dúvida, segundo Heidegger, que a verdade nessas quatro fases, e no significado completivo do mito, deva ser entendida como Unverborgenheit - desocultação. "Verdade significa, inicialmente, aquilo que é arrancado a alguma coisa que está escondida. A verdade é, portanto, esta 'entrada' (Entringung) no modo do 'descobrimento" (Entbergung)" (HEIDEGGER, p. 32).

Todavia, no próprio mito da caverna termina por vir à luz um outro significado de verdade, aquele significado que orientará o pensamento sucessivo rumo à concepção, assim chamada, da verdade como ade quação ou conformidade. Se se presta atenção, observa Heidegger, a Unverborgenheit - desocultação - vem tomada em consideração, enquanto rende acessivel alguma coisa que aparece no seu mostrar-se, e rende visivel essa alguma coisa que se mostra: essa alguma coisa é a ideia. O verdadeiro e próprio conhecimento, portanto, compete à ideia. A ideia é o puro resplandecer no sentido da frase: o sol resplandece, isto é, no sentido de revelar-se com clareza (Scheinen), não no sentido de aparecer (Erscheinen), como se se tratasse de uma pura e simples aparência por trás da qual existisse alguma outra coisa. Por trás da ideia, não existe nada: é ela mesma que se mostra resplandecendo (das Scheinsame). Aquilo que a ideia leva à vista e, portanto, dá a ver, é a verdade daquilo que ela mesma mostra no seu resplan- 
decer. A verdade vem, assim, concebida, antes de tudo e unicamente, como aquilo que se aprende no aprender da ideia. Portanto, a verdade significa aquilo que é acessivel através do resplandecer da ideia. Mas, assim como este acesso à ideia vem realizado mediante um "ver", a verdade se resolve em uma relação com o ver, é relativa ao ver. Ora, se aquilo que importa é a vista da ideia, a verdade no significado originário de Unverborgenheit perde o seu primado diante da ideia, "se apresenta sob o jugo da ideia". E, portanto, de agora em diante, todo esforço deve ser empregado para render possivel a vista da ideia. A esse fim, é necessário o "olhar retamente"; e de fato a passagem de uma fase à outra do mito da caverna é determinada pelo fato que o olhar se torna sempre mais "reto", sempre mais adequado. Mas, então, é evidente que a verdade será, consequentemente, encontrada na adequabilidade, na exatidão (Richtigkeit) do olhar. Nesse modo, partindo do primado da ideia sobre a verdade, entendida como Unverborgenheit desocultamento, há lugar uma transformação da essência mesma da verdade, a qual consiste na adequação da aprendizagem e do juízo. Nesta transformação, muda também a sede da verdade, que, desde que é Unverborgenheit, é um traço fundamental do próprio ente, enquanto, concebida como adequação, torna-se uma característica do comportamento humano diante do ente. Na doutrina platônica da verdade, permanece ainda uma necessária ambiguidade entre os dois significados de verdade. Essa mesma ambiguidade permanece em Aristóteles, mas agora a sede da verdade e da falsidade é o juízo; e desaparece, em Aristóteles, toda referência à Unverborgenheit. A verdade é, agora, entendida somente como adequação. E é essa a definição de verdade que se torna decisiva para todo o pensamento ocidental (Santo Tomás, Descartes, Nietzsche).

A metafísica ocidental, como aparece agora claramente no ensaio precedente, é caracterizada, segundo Heidegger, pela concepção da verdade como conformidade, tendo sede no juízo. A descoberta do significado originário da verdade assume, portanto, em Heidegger, o significado, ou pelo menos sugere a indicação para uma revisão da história da filosofia de Platão a hoje, ou, com as próprias palavras do autor, para uma superação da metafísica. Não por nada, ele fala em uma nota, introduzida no ensaio sobre a essência da verdade, sobre revolução na interrogação metafísica (HEIDEGGER, p. 105). Como se vê, a impostação, acima descrita, dada ao problema da verdade, há, nas intenções explicitamente declaradas do seu sustentador, uma importância resolutiva. $\mathrm{O}$ reencontro da concepção originária da verdade põe em questão a filosofia como foi concebida até aqui. Por quanto a vida da cultura contemporânea tenha nos habituado aos radicalismos, às posições explosivas e eversivas, às fúrias de recomeçar do começo, creio que em filosofia, ao menos depois de Nietzsche, não se tenha apresentado um furor de antitradicionalismo mais insidioso e insistente do que aquele que Heidegger mostra nesses últimos escritos: furor, note-se, mais pela intenção e os efeitos, que pela expressão, a qual é sempre, ao contrário daquela incandescente de Nietzsche, calma, pacata, separada dos sentimentos, parca de palavras.

A metafísica tradicional, que constitui a essência do pensamento ocidental, começa com a subordinação da verdade, como atributo do ser, à ideia; e da consequente consideração da verdade como adequação à ideia. O homem, como ser racional, deve atingir quanto mais possivel claramente a visão das ideias, que é a posse da verdade. Onde a concepção metafísica domina e dirige a mesma função educativa que tende a levar o homem, liberando-o de todos os impedimentos que o retêm e o desgastam no viver irracional das paixões, à posse da verdade, que consiste na excelência do ser-humano. O início da metafísica no pensamento de Platão é, portanto, também o início do humanismo. Aqui, humanismo significa, no seu sentido mais amplo, o evento ligado ao início, ao desenvolvimento e ao fim da metafísica, pelo qual o homem, "em vários aspectos, mas, em todo modo, conscientemente se encontra no meio daquilo que é, sem por isso ser o ente supremo" (HEIDEGGER, p. 49).

Entende-se que a revisão ou a superação da metafísica deveria levar consigo à revisão ou à 
superação do humanismo. Portanto, a filosofia heideggeriana é uma filosofia anti-humanista? Essa é a pergunta que lhe põe Jean Beaufret e provoca a resposta da Carta sobre o humanismo (Brief über den Humanismus), publicada junto com o escrito de interpretação platônica. Mas o que significa "filosofia anti-humanista? Em uma época em que todas as filosofias, do espiritualismo ao marxismo, passando pelo existencialismo, declaram-se humanistas, e reclamam, cada uma para si, a parte maior, e, segundo os diversos pontos de vista, mais genuína, do humanismo, há ainda sentido falar de humanismo e de anti-humanismo filosófico?

A esses interrogativos, Heidegger responde na carta citada, que é - note-se, o único escrito verdadeiramente recente entre aqueles examinados até aqui (a carta do Beaufret, que provoca a resposta, é datada em 10 de novembro de 1949). Essa carta é extremamente iluminante, porque representa quase um rápido olhar retrospectivo, mais maduro e mais geral, dado por Heidegger aos temas fundamentais da sua pesquisa, postos em confronto com as mais comuns objeções, resumidos e projetados em uma perspectiva larguíssima de trabalho filosófico ainda a ser realizado. A linguagem, nessa carta, tornou-se muito mais filtrada (o que não quer dizer menos abstrusa), menos amaneirada e mais genuina, menos pedante e mais caprichosa, e, mesmo permanecendo esotérica, mais limpida, na tentativa - que me parece ademais evidentíssimo - de atingir e desfrutar a eficácia evocativa da linguagem poética para exprimir ideias, sem por isso renunciar totalmente ao esclarecimento conceitual.

Para esclarecer o significado do humanismo, para Heidegger se trata de pensar em modo mais originário, em modo mais "essencial", a essência do homem. O significado tradicional de humanismo é ligado ao destino da metafísica. Todo humanismo se funda sobre uma metafisica ou se põe, ele próprio, como fundamento de uma metafísica. Ora, a metafísica pressupõe o ente, mas não põe em questão a verdade do Ser; e não a põe porque não a pode pôr, porque o problema da verdade do Ser é inacessivel à metafísica enquanto tal. Segundo a metafísica e, portanto, segundo o humanismo que sobre ela se funda, o homem é o animal racional; mas essa definição é válida dentro dos limites da metafísica, enquanto é condicionada pela metafísica que pensa o ente, mas não a verdade do ser. Para atingir a essência mais originária do homem, precisa ultrapassar a metafisica e problematizar a verdade do ser. Então, o homem se revela na sua essência originária, que consiste no "estar à luz do ser". Mas esse estar à luz do ser é aquilo que Heidegger mesmo já tinha chamado, nas obras precedentes, "existência", no sentido muitas vezes esclarecido de projetar-se rumo ao Ser, de um "instar estático na verdade do Ser". Portanto, a essência do homem, não mais condicionada pela metafísica, mas pensada à luz de um pensamento que põe em problema a verdade do Ser, está na existência. Essa existência não deve ser entendida no sentido tradicional, segundo a qual ela se contrapõe à essentia, como actus à potentia (e aqui encontra lugar uma rejeição do existencialismo de Sartre, que considera ainda a contraposição de essentia e existentia nesse sentido tradicional), mas no sentido, revelado já em Sein und Zeit, segundo o qual a essência originária do homem está em somente o homem ser, dentre todos os outros seres, investido pela verdade do ser; assim que ele, jogado do ser na verdade do ser, está cuidando, existindo da verdade do ser de modo que apareça, à luz do ser, o ente como aquilo que é. O homem não teve do Ser o encargo de fazer dissolver, como sujeito, o ente na tão decantada objetividade. $O$ destino do homem é de vigiar sobre a verdade do Ser; e, aqui, improvisamente, a partir da ideia da vigilância uma metáfora incrivelmente especiosa: o homem é o pastor (o guardião) do ser (HEIDEGGER, p. 75).

Até a esse ponto, segundo Heidegger, os humanismos tradicionais nunca chegaram; isto é, eles não puseram suficientemente em alto a humanitas do homem, dado que a supremacia do homem não está no ser sujeito, presumido dominador e real destruidor do Ser, mas no estar próximo ao Ser, na proximidade do Ser, de ser o vizinho do Ser. Confutar o humanismo, assim como foi entendido até agora, quer dizer talvez afirmar 
aquilo que não é humano? Absolutamente não: quer dizer, ao invés, fazer o homem reencontrar a sua essência originária, fazer o homem retornar na sua pátria, que é a proximidade ao Ser, aquele homem que hoje se encontra perdido, sem pátria, abandonado, como é, no esquecimento do ser. O ser sem pátria do homem (Heimatlosigkeit - apatricidade) consiste no esquecimento do ser, onde a verdade do ser permanece não pensada, e onde se preocupa somente do ente, das determinações particulares do ser. Certo, esse retorno em pátria do homem esquecido não é coisa que se realize de hoje para amanhã. Se nós nos perguntamos, hoje, o que é o Ser, não podemos dar outra resposta senão que o Ser é si mesmo; e o prová-lo e o dizê-lo compete ao pensamento futuro. Aquilo que podemos dizer - afirma Heidegger - é somente isto: o Ser é aquilo que existe de mais próximo ao homem; o Ser é o próximo (das Nachste), mesmo se essa proximidade permanece distantíssima ao homem. Desde o princípio, o homem se sente, sempre e somente, próximo a cada coisa que é. Mas é evidente que se o pensamento apresenta a si o ente como ente, não pode não se referir ao Ser. No entanto, é exatamente esse Ser, ao qual cada ente remete, que escapa à metafísica. E o homem, esquecendo o Ser para o ente, desconhece aquilo que é mais próximo; e vai além, e crê que aquilo que está além seja aquilo que é mais próximo. " $E$, no entanto, mais próximo do que aquilo que é próximo - mesmo se, para o pensamento corrente, mais distante do que aquilo que é remoto - é a proximidade mesma: a verdade do Ser" (HEIDEGGER, p. 77).

Dever-se-á dizer que essas teses (duas são as teses fundamentais: "o Ser é o próximo do homem", e "o homem está à guarda do Ser", e ambas são expressas com metáforas) têm muito mais o tom e a sugestão da revelação poética que aquela da reflexão filosófica: o próprio Heidegger está convencido disso, e não se perturbaria pela objeção. Ainda uma vez, nesse ensaio, cita o seu poeta predileto, Hölderlin, cujo pensamento considera mais originário e mais voltado ao futuro do que aquele de Goethe (HEIDEGGER, p. 86). As Tra- gédias de Sófocles, ele disse em um outro ponto (HEIDEGGER, p. 106), revelam o ethos em forma mais originária do que as lições de Aristóteles sobre a Ética. Os poetas são mais primitivos, isto é, mais próximos à origem que não os pensadores sistemáticos. E o "retorno às origens", o "gosto do primitivo" (mito de todo grande decadentismo, de uma cultura "sem pátria" na sociedade em que se exprime, mas que não exprime) é o tema fundamental da Weltanschauung - visão-de-mundo - heideggeriana, como se delineia com clareza nesse último ensaio.

Esse retorno às origens, Heidegger o anuncia a nós como um programa de trabalho para o pensamento futuro. O seu dizer de hoje não há outra pretensão que aquela de oferecer aquilo que deve ser ainda pensado (das Zu-denkende - a se pensar). Não pretende dar uma resposta à pergunta, somente anunciada como pergunta, sobre a verdade do Ser. Aquilo que sabe e sobre o qual insiste é que a filosofia até hoje, desviada por uma falsa concepção da verdade e do homem, nem mesmo chegou a entrever o problema que somente a consideração do homem como "existência" revelou e pôs em tema. Ele as ancora e repete que aquilo que ele revela é uma coisa extremamente simples: "Aquilo que surpreende nesse pensar o ser é a sua simplicidade" (HEIDEGGER, p. 116); e que exatamente a essa simplicidade originária, primitiva, auroral, precisa voltar, àquela simplicidade da qual a filosofia perdeu o sabor e a paixão.

\begin{abstract}
Porque neste pensamento deve ser pensado algo de simples, assim resulta difícil ao modo de apresentar, transmitido como filosofia. Só que o difícil não consiste no perder-se em uma particular profundidade e formar conceitos complicados, mas se esconde no passo atrás que faz entrar o pensamento em um perguntar que procede experimentando e faz cair o modo habitual de pensar próprio da filosofia (HEIDEGGER, p. 91).
\end{abstract}

Enfim, não pretende ter dado grandes passos, mas aqueles poucos passos realizados pelo seu pensamento ele considera que não tenham sido ainda superados pelo pensamento contemporâneo (existe aqui uma alusão também a Jaspers) (HEIDEGGER, p. 92). Se o caminho empreendido por ele seja um beco sem saída não se pode 
dizer olhando a partir de fora e de longe; pode julgá-lo somente quem tenta percorrer a estrada ou indicar uma estrada melhor. Donde o convite que ele dirige aos pensadores contemporâneos a permanecerem, ainda em futuro próximo, sobre o caminho, como viajantes na proximidade do Ser.

O essencial para a renovação profunda no pensar é, para Heidegger, a recusa à subjugação do pensamento à ação, que reduz a filosofia ao nivel de toda outra ciência; a condenação da interpretação técnica do pensamento no qual vai perdido o Ser como elemento do pensamento. Por causa dela

[...] se avalia o pensamento com uma medida inadequada. Esta avaliação assemelha ao procedimento de quem buscasse de medir a natureza e a capacidade de um peixe pelo tempo em que ele é capaz de viver fora d'água". Já há tempo, há demasiado tempo, o pensamento está fora d'água. Talvez pode-se chamar "irracionalismo" - ele se pergunta - o esforço de levar novamente o pensamento ao seu elemento? (HEIDEGGER, p. 55).

Levar o pensamento ao seu elemento quer dizer reaproximar o pensamento ao Ser; enquanto saida fora do seu elemento, a filosofia se torna uma técnica. E então: "não se pensa mais, ocupa-se de filosofia" (HEIDEGGER, p. 58). Naturalmente, não se trata de falar sobre a verdade do Ser. Trata-se de que o pensamento venha à língua, que no seu dizer leve à língua a palavra inesperada do Ser. A língua é a moradia do Ser; e nessa moradia habita o homem. E a língua exige muito menos a precipitada expressão que não o reto silêncio.

Três advertências se leem ao final dessa carta, quase como custódia da dignidade do pensar e como guia para o renascimento do filosofar: "rigor da reflexão, acuidade do dizer, sobriedade de palavras". E depois se reforça: menos filosofia, mais circunspecção no pensar; menos literatura, porém, mais cura da letra. E, na despedida, uma previsão: o pensamento futuro não será nem uma filosofia nem o hegeliano amor da sapiência. $O$ que será? Seguem palavras sibilinas:

O pensamento desce na pobreza da sua essência provisória. O pensamento aduna a linguagem no simples dizer. A linguagem é, assim, a linguagem do Ser, como as nuvens são as nuvens do céu. O pensamento traça, com o seu dizer, invisiveis sulcos na linguagem. Mais invisiveis do que aqueles que lentamente traça o agricultor no campo (HEIDEGGER, p. 119).

\section{Referências}

BOBBIO, Norberto. Tre scritti brevi di Heidegger. Rivista di Filosofia, v. 39, n. 3. p. 1-16, 1948.

\section{Jose Francisco de Assis}

Doutor em Filosofia pela Pontifícia Universidade Urbaniana, Città del Vaticano, Roma, Itália; professor da Universidade Estadual do Oeste do Paraná (Unioeste), em Toledo, PR, Brasil.

\section{Daniela Valentini}

Licencianda em Letras "Português-Italiano", na Universidade Estadual do Oeste do Paraná (Unioste), em Cascavel, PR, Brasil; professora de italiano na Universidade Estadual do Oeste do Paraná (Unioeste) e no Centro de Ensino de Linguas de Toledo (CELTO) e na Escola de idiomas POLYS IDIOMAS, em Toledo, PR, Brasil.

\section{Endereço para correspondência}

Daniela Valentini

Universidade Estadual do Oeste do Paraná

Rua da Faculdade, 645, Protocolo Geral, CCHS

Jardim La Salle, 85903-000

Toledo, PR, Brasil

Os textos deste artigo foram revisados pela Poá Comunicação e submetidos para validação do autor antes da publicação. 